\title{
Thoughts on Teaching of "Automobile Theory" Based on the Mode of Secondary Vocational Education and Application-Oriented Undergraduate Education
}

\author{
Yongfang Li, Yali Yang \\ School of Mechanical and Automotive Engineering, Shanghai University of Engineering Science, Shanghai, China \\ Email: muzicandy@126.com
}

\begin{abstract}
How to cite this paper: Li, Y.F. and Yang, Y.L. (2020) Thoughts on Teaching of "Automobile Theory" Based on the Mode of Secondary Vocational Education and Application-Oriented Undergraduate Education. Open Access Library Journal, 7: e6576.

https://doi.org/10.4236/oalib.1106576
\end{abstract}

Received: July 4, 2020

Accepted: July 25, 2020

Published: July 28, 2020

Copyright $\odot 2020$ by author(s) and Open Access Library Inc.

This work is licensed under the Creative Commons Attribution International License (CC BY 4.0).

http://creativecommons.org/licenses/by/4.0/

\begin{abstract}
This paper focuses on the theoretical knowledge and practical experience accumulated by students in the mode of secondary vocational education and application-oriented undergraduate education integration (hereinafter referred to as "secondary vocational education and application-oriented undergraduate education"), and carries out corresponding thoughts for the teaching of this course.
\end{abstract}

\section{Subject Areas}

Education

\section{Keywords}

Automobile Theory, Secondary Vocational Education and Application-Oriented Undergraduate Education, Course Reform

\section{1. 引言}

2014 年, “中本贯通” 的试点招生工作在上海正式启动, 随后几年不断 加大试点范围, 已成为中考招生的一大亮点, 备受考生和家长的关注。目前 已有上海第二工业大学、上海工程技术大学等 40 余所高校设置有中本贯通专 业。“中本贯通” 即 3 年中职教育与 4 年应用本科教育贯通, 学制为 7 年, 其专业一般是操作性较强的技术技能型专业, 旨在让学生学到扎实的基础理 论知识, 并且能熟练地掌握相关专业的职业技能, 从而实现把中本贯通教育 下的学生培养为能符合国家未来产业发展需要的高水平技术技能型人才 [1]。 
该教育模式下, 中职学生毕业后, 需通过转段考试升为本科。中职学习阶段 突出任务导向, 而本科学习阶段则应加强理论和复杂的情境化教学, 在教学 实践中应以解决实际问题为目标, 通过真实情境的创设, 不断提出问题和解 决问题, 培养学生的批判性思维和技术创新能力 [2]。

“汽车理论” 作为汽车类专业的核心课程, 更是汽车服务工程中本贯通 专业的必修专业课。对于结束了三年中等职业教育, 已经步入四年本科教育 的学生, 他们已经拥有了一定的职业相关知识和实践运用能力。但由于中职 教育的师资力量、教学资源等方面的不足, 学生的实践经验、职业技能可能 相对较强, 而对应的理论知识储备则相对较弱。在对学生培养方案上应打破 原有的中职教育和本科教育各自独立的课程体系框架, 从更符合中本贯通教 育模式下学生的认知思维发展规律以及职业技能训练要求出发, 不断从 “汽 车理论” 课程的教学方法、课程内容结构、课程考核模式等方面进行优化改 进, 为就业市场培养优秀的应用发展型人才。

\section{2. 教学内容的思考}

\section{1. 理论教学内容}

汽车理论课程主要讲述汽车的动力性、燃油经济性、汽车动力参数的选 定、制动性、操纵稳定性、平顺性及通过性。学生应掌握汽车运动、受力的 基本规律, 掌握汽车主要技术性能的评价指标、计算方法和影响因素, 学会 从理论上分析汽车性能的基本方法。但汽车理论课程本身理论性强、涉及的 概念和技术与工程实践的关系非常密切, 而大多数学生对这些概念和技术十 分模糊, 感性认识不深, 理论联系实际的能力弱 [3]。因此, 针对中本贯通专 业的汽车理论课程, 授课教师应对课程内容应重新思考和整合, 对课程知识 要点、重难点进行分析和梳理, 确定本课程适合中本贯通专业的基本教学内 容和要求。

加强多门课程间交叉内容的融合 [3]。汽车理论涉及多门课程内容, 如在 汽车制动性以及制动力分配部分, 涉及到汽车制动系的结构, 而制动系结构 在汽车构造、汽车设计等课程中都有讲解, 还涉及到理论力学等知识。因此, 教师必须合理整合课程之间的交叉内容, 让学生全面了解专业课程体系, 这 样才能激发学生对该课程的学习兴趣, 达到主动学习的目的。

\section{2. 实践教学内容}

汽车理论是一门理论和实践紧密结合的课程。学生在课堂教学中学习相 关理论知识, 然后通过实践加深感性认识, 巩固对理论知识的理解。特别是 针对中本贯通的学生, 理论基础较薄弱, 加强实践教学就显得更加重要了。 教师可以组织一些验证性实验、综合性实验和设计性实验。明确实验目的、 实验要求和实验条件, 可以由学生设计实验方法、实验方案, 选择实验器材 拟定实验程序, 并对实验结果进行处理分析。通过实验实践过程, 可以提高 学生学习的积极性和主动性, 加深对知识的理解, 切实做到理论联系实际。

目前由于受到实验场地、实验设备和实验人员的限制, 导致大部分的高 校仍然只能开设较少的实验, 而且实验主要是由老师示范讲解, 学生实际操 
作的很少。还有一些特殊情况, 比如危险工况的实验、紧急制动实验、冰雪 路面实验等, 也是很难实现的。这就需要建立虚拟仿真实验平台 [4], 以弥补 实验条件的不足。

\section{3. 教学方法的思考}

努力实施项目教学和实例教学, 引入车辆性能仿真软件。以项目实例充 实教学内容, 把项目实例贯穿于课堂教学中, 主要培养学生的设计能力和灵 活运用所掌握知识解决实际问题的能力, 以加强学生对理论的理解, 从而提 高教学质量。比如, 以实例形式利用 MATLAB 软件对汽车各大系统进行仿真 及优化设计。每个实例都有任务描述和完成任务所实施的过程。所有实例都 有数学模型的建立和仿真程序的编写, 而且仿真程序都需经过调试, 并可在 MATLAB 软件中直接运行并获得仿真结果, 这样能巩固理论知识点, 扩展学 生的知识面。

教学手段上, 重视多媒体的建设和动手实践能力的培养。建立起一套完 整的资料库, 包括多媒体资料库、习题库等。既全面系统介绍本课程理论知 识体系, 又注重该理论在实际生产活动中的具体应用。力争做到理论系统、 案例经典、内容翔实、资料充分, 能够满足 “学时要精、内容要新、水平要 高” 的教学要求, 既便于学生自学, 又要对教师授课起到一定的辅导作用。

在每一次课程理论教学和实践教学完成后, 及时总结这次教学过程可以 改进的地方。把教学内容、能力培养、素质培养和教学过程等四个方面结合 起来, 查找存在的问题并及时改进。及时收集学生对本次教学过程的反馈信 息, 以进一步的对教学做出适当的调整和改进。

\section{4. 课程考核的思考}

为了突出评价中本贯通学生的综合素质, 必须改变传统期末考试定成绩 的考评方法。以往该课程期末理论考试所占的比例较高, 约 70\% 80\%, 然后 是出勤和课堂表现等占 $20 \%$ 30\%。对于中本贯通的学生, 由于本课程加强了 实践教学内容, 因此应当提高实践部分所占的比例。该课程的综合成绩分成 理论和实践 2 部分, 其中期末理论考试部分可占 50\% 60\%, 实践部分可占 $40 \%$ 50\%, 这样加强学生实践部分的学习, 才能更好的理解相应的理论知识。 理论部分包括期末试卷测验、课后作业和课堂表现等。实践部分主要包括对 于实验室提供的试验进行的方案设计等实际操作以及基于仿真软件进行的项 目实验模拟考核。这种考核模式在一定程度上缓解了传统考核模式的弊端, 将重点考察理论学习改为理论知识与实践内容一同考察, 让学生亲自动手体 验这门课程所包含的内容, 加强学生更好地学习与理解这门课程的知识内容。

\section{5. 结语}

“汽车理论” 课程是汽车类专业的核心课程, 其课程的学习对学生以后 的就业发展有很大的帮助。为提高中本贯通教育模式下人才培养的质量, 需 要对汽车理论这门课程从课程大纲、课程内容、教学方法、教学手段、考核 方式等各方面进行必要的改革。然而, 中本贯通的教育模式刚刚起步, 该课 
程的改革还处于实践摸索阶段, 后续还应当根据实际教学情况随时做出合理 的更新, 进一步加强课程教学的建设。

\section{Conflicts of Interest}

The authors declare no conflicts of interest regarding the publication of this paper.

\section{References}

[1] 岳玉静. “中本贯通” 数学课程教学思考[J]. 新校园: 阅读版, 2018(1): 67.

[2] 杨梅, 张利华, 王浩, 黄金金山. 中本贯通人才培养模式的几点思考 [J]. 科教导刊 (下旬), 2018, 327(1): 45-46.

[3] 杨英. 汽车理论课程教学内容的整合与实践 [J]. 科学咨询, 2015(25): 121-122, 123.

[4] 侯献军, 唐蜜, 张国方, 等. 面向全产业链的汽车虚拟仿真实验教学中心建设与 发展 [J]. 实验技术与管理, 2017(2): 6-11. 